\title{
An Analysis On The Strategies Used To Translate Idioms With Reference To J.K. Rowling's Novel Entitled Harry Potter And The Philosopher's Stone
}

\author{
Nurkasiyati \\ English Educational Departement, PGRI University of Banyuwangi
}

$\begin{array}{ll}\text { Received } & \text { : Tuesday, April 17, } 2018 \\ \text { Revised } & \text { : Tuesday, April 24, } 2018 \\ \text { Accepted } & \text { : Monday, April 30, } 2018\end{array}$

Abstract

This research is conducted to identify the idiom and its types in Joanne Kathleen Rowling's novel entitled Harry Potter and the Sorcerer's Stone as well as strategies used to translate them in the translation version

The data of this descriptive qualitative research are idiomatic expressions found in the novel and its translation in Indonesian language. Documentation is used to collect the data. The data of this research are phrases or sentences that contain idiomatic expressions. Meanwhile, content analysis method is applied for analyzing data in relation to their contexts.

The result of this research shows that 140 idioms in 13 types were found in the English novel from chapter 15 to chapter 17. Those thirteen types are phrasal verb (61.43\%), prepositional phrase (13.57\%), semi-opaque idiom (7.86\%), noun phrase $(5 \%)$, clause idiom $(4.29 \%)$, idiom of comparison $(2.86 \%)$, miscellaneous $(1.43 \%)$, proverb $(0.71 \%)$, adverb phrase $(0.71 \%)$, adjective phrase $(0.71 \%)$, idiomatic pairs $(0.71 \%)$, and simile $(0.71 \%)$.

Furthermore, there are three translation strategies used by the translator. They are translation using an idiom of similar meaning but dissimilar form, paraphrase, and omission. The researcher found that paraphrase is the highest number with 134 idioms (95.7\%). The second strategy is translation by using an idiom of similar meaning but dissimilar form with 5 idioms (3.59\%). The less strategy used by the translator is translation by omission with only one idiom $(0.71 \%)$. It can be concluded that paraphrase is the most preferred strategy used by the translator. It was used because she wants to deliver the message of the text as natural as possible by using the most equivalent meaning of the idiom in Indonesian

Keywords:Idioms; Translation Strategies

\section{A. Introduction}

Idioms are considered to be one of the hardest and most interesting parts of the English vocabulary. On the other hand, they are considered one of the most peculiar parts of the language. Furthermore, idioms are difficult to translate because of their unpredictable meaning and grammar. Moreover, idioms may be culture-bound and this may 
cause even greater problems for the translator. Therefore, in order to transfer an idiom into the TL the translator must choose the most appropriate strategy. The translator must learn a lot about the function of idioms in the SL and the TL. She or he must know the characteristics of idioms in both languages. Moreover, in order to deal with the problems that arise in the process of translation, translators use various strategies. The examination and classification of strategies is very useful and helpful for the work of translator.

Specifically, this research focuses on J.K. Rowling's novel entitled Harry Potter and the Philosopher's Stone and its Indonesian translation Harry Potter dan Batu Bertuah. This novel is chosen because it contains English idioms in suchgreat quantities, and also it has its Indonesian translated version to provide the research data. Furthermore, due to language-cultural specific and non-literalness that idioms carry, the researcher is interested in analyzing the translation of idioms in the novel regarding to its equivalent result. The researcher is also interested to identify the strategies used by translator and how those applied strategies work. These preceding points are the main concerns of this research.

\section{Problems of the research}

Based on the background of the research above, the problems of this research are formulated as follows:

1. What types of idioms are found in J.K. Rowling's Harry Potter and the Philosopher's Stone?

2. What are the strategies used to translate idioms in J.K. Rowling's Harry Potter and the Philosopher's Stone?

\section{Objective of the research}

The objectives of this research as the answers of the problems above can be described as follows:

To identify the types of idioms found in J.K. Rowling's Harry Potter and the Philosopher's Stone.

To identify the strategies used to translate idioms into Indonesian in J.K. Rowling's Harry Potter and the Philosopher's Stone

\section{Significance of the research}

The result of the research is expected to give some advantages to the following people

a. The translators

This research can be used as a reference by translators in choosing the appropriate translation strategies in translating English idioms into Indonesian

b. The other researchers

It is hoped that the result will provide a good reference in analyzing idioms translation strategies for the other researchers.

c. The educational people

It is hoped that this thesis will give contribution to the educational people such as the teacher and the students as well. This research can be used by teachers as material to 
teach translation about idioms and its translation strategies. Furthermore, it can give benefit to develop the learners' or students' understanding about English especially the idioms

\section{Scope of the research}

Due to the limit of time the researcher decided to analyze only chapter 15- chapter 17. The main topic of this research is strategies used to translate idioms. This research focuses on translation as a product, more specifically on words, phrases, or expressions closely related to idiom from English into Indonesian. The research analysis focuses on how the translator translates the English idioms into Indonesian, what strategies used by the translator to translate idiom. The data are restricted only on idioms that found in the J.K. Rowling's Novel entitled Harry Potter and the Philosopher's Stone and its translation in the Indonesian version.

\section{Strategies to Translate Idioms}

Translation strategy as a part of translation process is a procedure used by the translator to overcome the translation problems (Lorscher as cited in Silalahi,

2009: 28). In addition, Suryawinata as cited in Indiarti (2013: 5) defined translation strategy as tactic to translate word, or even a full sentence that cannot be divided into smaller unit to be translated. It can be concluded that translation strategy is a way to settle down the problem in translation in order to produce a good translationthere have been many scholars writing about strategies used for rendering a text from SL into TL during the history of translation. In order to deliver the meaning of an idiomatic expression, a translator needs some strategies to translate the idiomatic expression into TL. As stated by Baker in Saputro (2012: 2), there are four strategies to translate idioms.

a. Using an idiom of similar meaning and form

This strategy involves using an idiom in the TL which conveys roughly the same meaning as the SL idiom and, in addition, consists of equivalent lexical items. This kind of match can only occasionally be achieved. For example

SL: We rarely dine out these weeks.

TL: Kita jarang makan di luar minggu ini

In this case, it is said to have similar meaning and form if it also has the idiomatic expression and phrasal verbs construction. The idiomatic expression dine out is translated into makan di luar in the TL because the SL and TL have idiomatic meanings and forms. And also the context is included into literal expression in the SL and $\mathrm{TL}$, because based on the form, it has similar literal element. It will be in the same constructions in meaning when it is translated back into English because of its similar meaning and form in both languages. That is why the translator uses the translation strategies of similar 
meaning and similar form because of the similar meaning and construction in this. Instead of the similarity in meaning, this idiomatic will be in same lexical item after it is translated back into English

b. Using an idiom of similar meaning but dissimilar form

It is sometimes possible to find an idiom or fixed expression in the TL which has a meaning similar to that of the source idiom or expression, but which consists of different lexical items

SL: It would twist itself round and look up in her face, with such a puzzled expression that she could not help bursting out laughing.

TL: Tapi, burung itu memutar dirinya dan menatap wajah Alice dengan sangat bingung sehingga Alice tidak dapat menahan diri untuk tertawa

According to Dictionary of American Idioms and Phrasal Verbs, the idiom could not help (doing something) means could not prevent or avoid on doing something. It means could not restrain, the word restrain refers to prevent oneself from doing something. Thus, idiomatically could not prevent means tidak dapat menahan diri. Therefore, both expressions in the SL and its translation in the TL refer to the same meaning. In terms of form, both expressions cannot be said as equivalent. If the idiomatic expression could not help translated literally, it will become tidak dapat menolong and it will be confusing to the reader

c. Translation by paraphrase

The most common way of translating idioms when a match cannot be found in the TL or when it seems inappropriate to use idiomatic language in the target text because of differences in stylistic preferences of the SL and TL.

SL: "Why you have rats suddenly decided to clean up your act?'

TL: 'Mengapa kalian para tikus tiba-tiba memutuskan untuk bersikap baik?'

The idiomatic expression clean up is analyzed based on the word class, the result is clean (verb) which mean bersih, and up (preposition) which means atas. However, if it is translates literally the meaning can be distorted. In order to make the meaning sounds more natural in the $\mathrm{TL}$, so it is translate

into bersikap baik. The researcher unable to find appropriate idiomatic expression in the TL to translate idiom 
clean up. It proves that the idiomatic expression is translated by paraphrase because of differences in style of the SL and TL

d. translation by Omission

An idiom may sometimes be omitted altogether in the target text for some reason. This may be because it has no close match in the $\mathrm{TL}$, its meaning cannot be easily paraphrased, or for stylistic reasons.

This strategy is done mostly in the sentence or paragraph level. The reason for this phenomenon is that when an idiomatic expression is omitted, nearly always there is a 'loss' in the meaning. To 'compensate' the resulting loss, one is obliged to mention some supplementary words in some parts of the sentence or paragraph where an omission has been done. The example is presented below to Alice

SL: 'Who are you talking to?' said the King coming up

TL: 'Kau sedang berbicara dengan siapa?' Tanya sang Raja kepada Alice

The phrase coming up is omitted because it would be of any use. It had better to omit one of these idiomatic expressions, so it would sound more natural in the TL.

\section{B. Previous Study}

In doing an analysis in this research, five works from other researchers are viewed in an intention to use it as main references of this research. The research about translation strategies of idioms have been conducted by many researchers

Most of them apply theory of idioms translation suggested by Baker. There are five previous studies that will be present to strengthen the implementation of this research.

The first is a thesis by Pratiwi entitled The Translation of Idioms in Rowling's Harry Potter and the Prisoner of Azkaban into Indonesia (2014). She concluded that to translate the 129 idioms found in Harry Potter and the Prisoner of Azkaban, the Indonesian translator used four types of strategies. Those four strategies are idiom to idiom, paraphrase, omission, and literal strategy. From the research, she found that the most preferred method to translate the idioms was paraphrase strategy (76\%). It was used because most of the idioms in source text have no match idioms in the target text, so they have to be translated by delivering the actual meaning. Second leading is literal strategy (17\%). Most of the idioms translated by this method are considered as phrasal verbs, such as blowup and back-off. Third strategy is idiom to idiom (5\%), which is divided into: idiom to idiom with the same form and meaning $(2,5 \%)$, and idiom to idiom with different form but similar meaning $(2,5 \%)$. This strategy is less dominant because finding two idioms with the same meaning in English and Indonesian is really difficult. 
Beside a thesis by Pratiwi another work is reviewed here. The study that was done by Mayasari in her thesis entitled Strategies Used for Idiom Translation in J.K. Rowling's Novel Entitled Harry Potter and the Goblet of Fire (2008) showed that the dominant strategy used by the translator was using an idiom of similar meaning and form. The strategies used by the translator in translating "Harry Potter and the Goblet of Fire" from English into Indonesian are the one

suggested by Mona Baker (1992) such as: (a) using an idiom of similar meaning and form, (b) using an idiom of similar meaning but dissimilar form, (c) translation by paraphrase, and (d) translation by omission.

The third work that also has been reviewed is done by Saputro (Idioms and Strategies of Translation in Harry Potter and the Deathly Hallows in Anglicist Volume 01 Number 02, 2012: 27). He concludes that the translator used four strategies proposed by Baker to translate the idioms in Harry Potter and the Deathly Hallows. As the result, the study showed several translation strategies are applied, which is include idioms of similar meaning and form, using an idiom of similar meaning but dissimilar form, translation by paraphrase, and translation by omission. Paraphrasing strategy mostly used because it enables translator to find equivalents in the $\mathrm{TL}$

The research about idiom also done by Suryanata (The Equivalence of English Idioms into Indonesia with References to the Translation of Gilbert's Eat, Pray, Love into Doa, Makan, Cinta: 2013). Based on this study, the semantic adjustments concerned in two ways, they are: (1) idiom to non-idiom, and (2) idiom to idiom. In general, the translator has used the natural form of the TL to avoid misinterpretation and be able to translate them well.

The last work that is being a reference was done by Sari. In her thesis entitled Strategies in Translating Idiomatic Expressions of Phrasal Verb in Terence Blacker's Bilingual Novel "Ms Wiz Goes Live" into :Ms Wis Jadi Bintang Televisi" by Mala Suhendra (2013). She found that the highest number of idioms was translated by using similar meaning and dissimilar form. Meanwhile,

there were no translation strategies of similar form and meaning. There were 45 idiomatic expressions found in this novel. The 43 idioms were translated using an idiom of similar meaning and form. The rest used paraphrase and omission strategies to translate idioms.

These five previous studies mentioned above become the important fundaments to accomplish this research about strategies to translate idioms in J.K. Rowling's novel entitled Harry Potter and the Philosopher's Stone.

\section{Research Method}

\section{Research Design}

This research applied descriptive qualitative approach method. It involves organizing, accounting and explaining the data (Cohen et al, 2007: 461). The qualitative research processes and analyzes the problems. It concerns with qualitative phenomenon, or 
more specially, the aspects relating to or involving quality or kind (Khotari, 2004: 3). The data were analyzed qualitatively because the characteristic of the data used is non-numerical data. The results of this study are descriptive data that will be presented in the form of words. It uses narrative in answering the questions

\section{Unit of Analysis}

The unit of analysis of this research was words or phrases that contained idiomatic expression taken from the English version of the novel and its translation in Indonesian version. Analysis of the data reveals the translation strategy that was applied by the translator.

\section{Data Collection Method}

The data of this research were collected by documentation method. The method was chosen because it has an influence on the quality of the data that can be used for interpretation (Flick, 2009: 303). In conducting this research, the data were collected by several stages; those are as listed below:

a. Preparing the instruments to collect the data such as pen, papers, and PC .

b. Taking both the novels, the English entitled Harry Potter and the Philosopher's Stone and its translation into Indonesian entitled Harry Potter dan Batu Bertuah.

c. Close reading of the data source, in this stage, the researcher read the novel attentively with the focus on the idiom expressions and their translations in the Indonesian version. The idiom expressions found in both novels were compared in searching for the equivalences.

d. Noting down the English idioms and their translation in Indonesian found in a paper completed with the page number and the sentences.

e. Putting all the data found in PC in order to make them easier to organize.

f. Selection of the Data. Furthermore, the data collected was purposively selected. The selection was done to search for the data to be described qualitatively. It was conducted in order that the data used is sufficient in terms of the number and is also able to represent the whole characteristics of all the data found.

\section{Data Analysis Method}

In order to accomplish the further analysis, the researcher used content analysis method. It is used to specify characteristic within the text that the researcher systematically works trough each transcript assigning code, which may be numbers or words (Dawson, 2002: 118)

The data were analyzed by identifying the types of idioms. Then, the data were categorized based on the translation strategies they belong to. Afterwards, the researcher quantifying the number of translation techniques implemented by the translator in the 
translation idioms into Indonesian. The number in each strategy is presented in form of percentage. After all those steps, the result was presented descriptively in order to make the result easier to comprehend.

\section{Data Analysis}

In this data analysis, the researcher presents the data that have been collected. This chapter is used to answer the question in Chapter I. In this chapter, the data that have been collected were analyzed and discussed to know the result of each activity during the research. The points discussed in this chapter are about the findings of the types of idioms and the translation strategies. For the further explanation, this chapter also provides the discussion of the findings that will be elaborated clearly.

\section{Findings}

Here the researcher presents about the findings of the research about types of idioms and strategies to translate idioms found in the novel Harry Potter and the Philosopher's Stone.

a. Types of Idioms

According to the research there are 140 idioms with 13 types found in chapter 15 to chapter 17 of Harry Potter and the Philosopher's Stone novel. The result of the research shows that 86 data are PV, 19 data are PP, 11 data are SOI, 7 data are NP, 6 data are $\mathrm{Cl}, 4$ data are IC, 2 data are Mis, 1 datum is proverb, 1 datum is AdvP, 1 datum is AdjP, 1 datum is IP, and 1 datum is simile.

The Number of the Types of Idioms is shown in the following table:

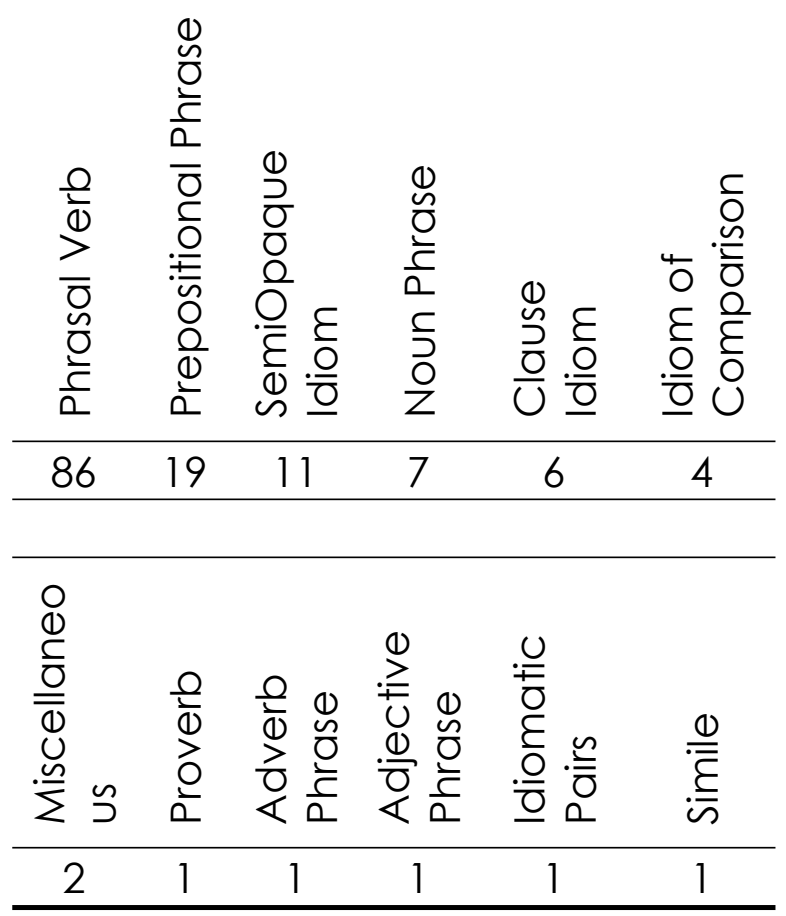


b. The translation strategies of Idioms

According to the result of the research, it was found that the translator using the strategies to translate idioms proposed by Baker. She used three strategies out of four. These three strategies were 1) translation using an idiom with similar meaning but different form, 2) translation by paraphrase, and 3) translation by omission. Furthermore, the researcher identified that 134 idioms were translated by paraphrase, 5 idioms were translated by using an idiom with similar meaning but dissimilar form and 1 idiom was translated by omission.

The frequency of the use of the strategies is shown in the table below:

Tabel 02. Frequency of Translation Strategy Usage

\begin{tabular}{clrc} 
No & \multicolumn{1}{c}{ Strategies } & Frequency & Percentage (\%) \\
1 & Paraphrase & 134 & 95.7 \\
& $\begin{array}{l}\text { An Idiom of Similar } \\
2\end{array}$ & & \\
meaning but & 5 & 3.59 \\
& $\begin{array}{l}\text { dissimilar form } \\
3\end{array}$ & & \\
Omission & 1 & 0.71 \\
& Total & 140 & 100
\end{tabular}

Based on the table, the data showed that paraphrase is strategy with the highest number of percentage. It means that the translator often used paraphrase strategy to translate idioms into Indonesian

\section{Discussion}

The Discussion of the strategies to translate idioms can be seen in the following analysis:

a. The Translation Strategies of Idioms

The translator uses some strategies proposed by baker to translate idioms in the novel. She used the dthree strategies out of four. Those strategies are 1) using an idiom of similar meaning but dissimilar form, 2) translation by paraphrase and 3) translation by omission.

b. Analysis of the strategies to translate Idioms

As explain in the as inform before, the data of this research were 140. From those data, 134 data were translated by paraphrase 5 data were translated by using an idiom of similar meaning but dissimilar form and only one datum were translated by omission. It is obvious that paraphrase is strategy to translate idiom with the highest number of usage. The translator applied paraphrase to translate idiom in most of the data because she wants to convey the message of the text as 
natural as possible. The translator picked out the words or phrases with the same level of meaning so that the reader thought as if it is non- translation text.

\section{E. Conclusion}

Through this section, this research comes to conclusions related to the problems of the research and the objectives of the research. In this study, the focus is in analyzing the strategies to translate idioms found in the novel Harry Potter and the Philosopher Stone and its Indonesian version. Two questions have been discussed; they are 1) what are idioms used in the novel, and 2) what are strategies used to translate idioms into Indonesian in the novel.

Several conclusions can be drawn after observing the translation result of idioms from Harry Potter and the Philosopher Stone and its Indonesian translation, specifically regarding the idioms expression. The significant findings are listed as follows

a. Types of Idioms

The first objective of this research is to identify the idioms used in the novel Harry Potter and the Philosopher's Stone. From the research that has been conducted, there were found thirteen types of idioms in the novel. Those thirteen types are phrasal verb, prepositional phrase, semi-opaque idiom, noun phrase, clause idiom, idiom of comparison, miscellaneous, proverb, adverb phrase, adjective phrase, idiomatic pairs, and simile. The result of the research shows that 86 data as the highest number are phrasal verb

b. The translation strategies of idioms

The second objective of this research is to identify the strategies used to translate the idioms into Indonesian. The research result shows that 140 idioms were found in the English novel from chapter 14 until chapter 17. The researcher found that paraphrase is the highest number with 134 idioms (95.7\%). The second strategy is translation by using an idiom of similar meaning but dissimilar form with 5 idioms (3.59\%). The less strategy used by the translator is translation by omission with only one idiom $(0.71 \%)$. It can be concluded that paraphrase is the most preferred strategy used by the translator. It was used because she wants to deliver the message of the text as natural as possible by using the most equivalent meaning of the idiom in Indonesian

\section{F. Acknowledgements}

First and foremost, heartfelt gratitude and thankfulness is due to The Merciful Allah Subhanahu wa ta'ala, The Creator and Provider, for all the favors and grace He has bestowed upon His creation.

In addition to thanking The Lord for guidance, I would like to show my gratitude to my first advisor H. Muhamad, M.Pd., for having a great patience in providing continuous and careful guidance as well as encouragement, indispensable suggestion and advice. 
My sincere thank is also expressed to my second advisor Yuli Sugianto, M.Pd., for having made such a good correction and valuable suggestion in the completion of this thesis

On this occasion, I would never forget to thank Wiwin Indiarti, S.S., M.Hum., as for her sincerely advice and motivation had unintentionally given me an idea for this research. I would also like to thank her for lending me her precious novel to be the object of this research.

Last but not least, I would like to express deepest gratitude to my beloved father for love, support and sincere pray in his life time. No matter how, he will always be there for me

\section{G. Rerefence}

Adelnia. Amineh and Dastjerdi, H.V. 2011. Translation of Idioms: A Hard Task for the Translator. Theory and Practice in Language Studies, Vol. 1, No. 7, pp. 879-883, July 2011

Akbari, Monireh. 2013. Strategies for Translating Idioms. Journal of Academic and Applied Studies (Special Issue on Applied Linguistics) Vol. 3(8) August 2013, pp.32-41

Cohen, Louis et al. 2007. Research Methods in Education (Sixth Edition). New York: Routledge.

Dawson, DR Catherine. 2002. Practical Research Methods: A UserFriendly Guide to Mastering Research. United Kingdom: How to Books Ltd.

Flick, Uwe. 2009. An Introduction to Qualitative Research. London: Sage.

In $\mathrm{d}$ i art i, W iwi $n$ a nd W ula $n$ W an gi. 2013. Per an I d eol ogi $d$ an Srat e gi Penerjemahan Terhadap Kualitas Terjemahan Istilah Budaya Using pada Publikasi Pariwisata Dwibahasa Kabupaten Banyuwangi. Banyuwangi: Universitas PGRI Banyuwangi.

Khotari, C.R. 2004. Research Methodology: Method and Techniques (2nd Revised Edition). New Delhi: New Age International Publisher. McCarthy and O'del. 2003. English Idioms in Use. Cambridge: CUP.

Munday, J. 2001. Introducing Translation Studies Theories and Applications. New York.

Murar, loana. 2009. Pragmatic and Functional Uses of Idioms. Retrieved on Februari 22, 2015 from http://cis01.central.ucv.ro/litere/activ st/articole anale lingvisti ca 2009/murar ioana.pdf

Novianti, Eva. 2012. An Analysis of the Translation Strategies of Idiomatic Expressions in Lewis Caroll's Alice in Wonderland in its 
Translation by Khairi Rumantati. Yogyakarta: English Language and Literature Study Program, English Educational Department, Faculty of Languages and Art, Yogyakarta State University. (Thesis)

Rowling, J.K. 1997. Harry Potter and the Philosopher's Stone. London: Bloomsbury

Rowling, J.K. 2000. Harry Potter dan Batu Bertuah. Jakarta: Gramedia

Saputro, Rizky Febriawan. 2012. Idioms and Strategies of Translation in Harry Potter and the Deathly Hallows. Anglicist Vol 01 No 02 (pp. 23-28) (August 2012).

Silalahi, Roswita. 2009. Dampak Teknik, Metode, dan Ideologi Penerjemahan pada Kualitas Terjemahan Teks MedicalSurgical Nursing dalam Bahasa Indonesia. Medan: Sumatera Utara State University (Disertasi)

Spears, Richard A. 2005. McGraw-Hill's Dictionary of American Idioms and Phrasal Verbs. USA: McGraw-Hill's Companies 